\title{
Author Correction: CRISPRi enables isoform- specific loss-of-function screens and identification of gastric cancer-specific isoform dependencies
}

Rebecca Davies ${ }^{1 \dagger}$, Ling Liu ${ }^{1 \dagger}$, Sheng Taotao $2,3,4,5,6,7$, Natasha Tuano ${ }^{1}$, Richa Chaturvedi' ${ }^{1}$, Kie Kyon Huang ${ }^{2,3,4,5,6,7}$, Catherine $\operatorname{Itman}^{8}$, Amit Mandoli' ${ }^{2}$, Aditi Qamra $2,3,4,5,6,7$, Changyuan $\mathrm{Hu}^{1}$, David Powell', Roger J. Daly ${ }^{1}$, Patrick Tan ${ }^{2,3,4,5,6,7^{*}}$ and Joseph Rosenbluh ${ }^{1,8^{*}}$

The original article can be found online at https://doi.org/10.1186/ s13059-021-02266-6.

* Correspondence: gmstanp@ dukenus.edu.sg; sefi.rosenbluh@ monash.edu

${ }^{\dagger}$ Rebecca Davies and Ling Liu contributed equally to this work. ${ }^{2}$ Program in Cancer and Stem Cell Biology, Duke-NUS Medical School, Singapore 169857, Singapore

${ }^{1}$ Cancer Research Program and Department of Biochemistry and Molecular Biology, Biomedicine Discovery Institute, Monash University, Clayton, VIC 3800, Australia

Full list of author information is available at the end of the article
Correction to: Genome Biol (2021) 22:47

https://doi.org/10.1186/s13059-021-02266-6

Following publication of the original paper [1], the authors reported an error. In Fig. 1c we have mistakenly mislabeled the sgRNAs. The corrected Fig. 1 is given in this correction article.

(c) The Author(s). 2021 Open Access This article is licensed under a Creative Commons Attribution 4.0 International License, which permits use, sharing, adaptation, distribution and reproduction in any medium or format, as long as you give appropriate credit to the original author(s) and the source, provide a link to the Creative Commons licence, and indicate if changes were made. The images or other third party material in this article are included in the article's Creative Commons licence, unless indicated otherwise in a credit line to the material. If material is not included in the article's Creative Commons licence and your intended use is not permitted by statutory regulation or exceeds the permitted use, you will need to obtain permission directly from the copyright holder. To view a copy of this licence, visit http://creativecommons.org/licenses/by/4.0/. The Creative Commons Public Domain Dedication waiver (http://creativecommons.org/publicdomain/zero/1.0/) applies to the data made available in this article, unless otherwise stated in a credit line to the data. 


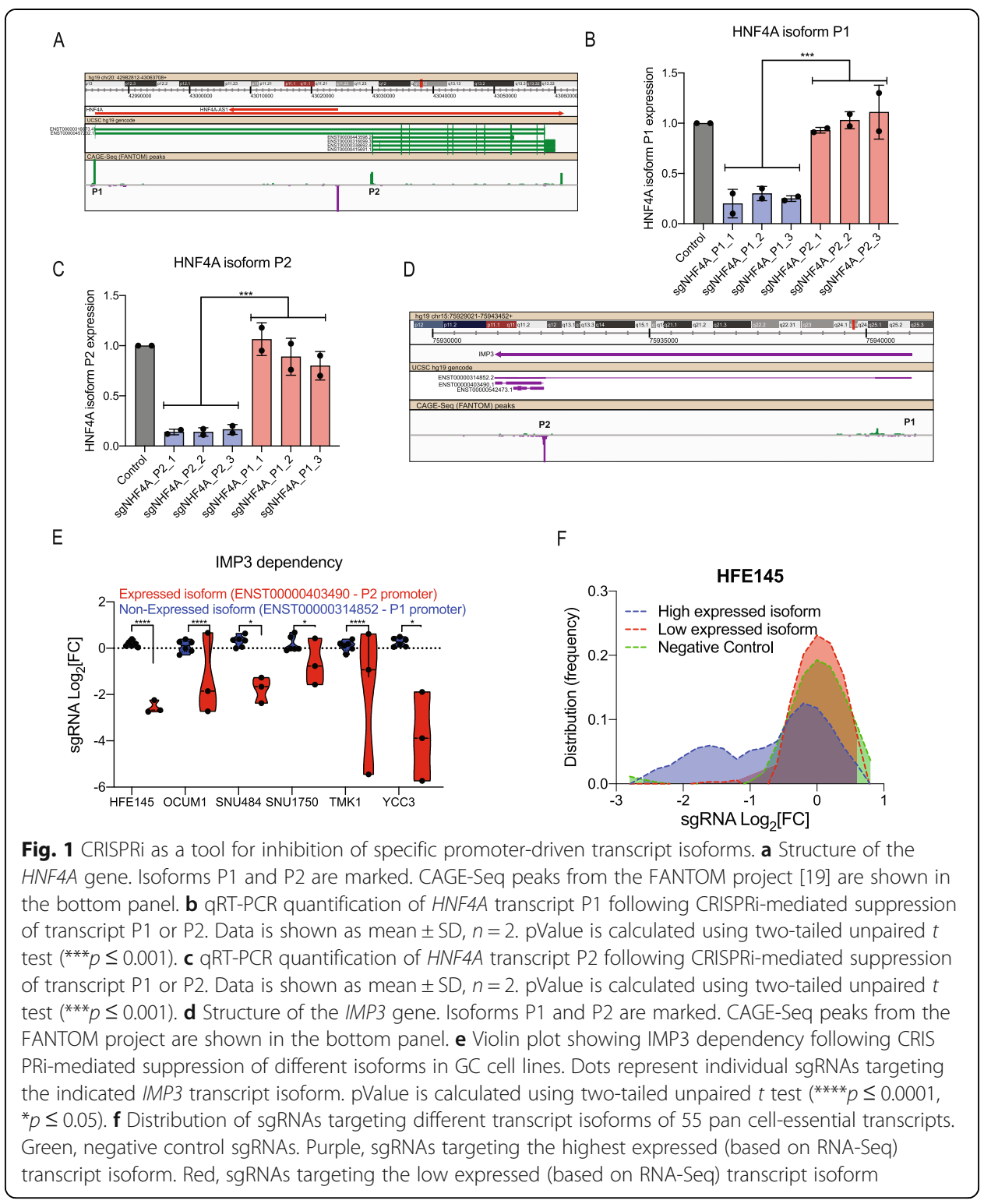

\section{Author details}

${ }^{1}$ Cancer Research Program and Department of Biochemistry and Molecular Biology, Biomedicine Discovery Institute, Monash University, Clayton, VIC 3800, Australia. ${ }^{2}$ Program in Cancer and Stem Cell Biology, Duke-NUS Medical School, Singapore 169857 , Singapore. ${ }^{3}$ Cancer Science Institute of Singapore, National University of Singapore, Singapore 117599, Singapore. ${ }^{4}$ Cancer Therapeutics and Stratified Oncology, Genome Institute of Singapore, Singapore 138672 , Singapore. ${ }^{5}$ SingHealth/Duke-NUS Institute of Precision Medicine, National Heart Centre Singapore, Singapore 169856, Singapore. ${ }^{6}$ Cellular and Molecular Research, National Cancer Centre, Singapore 169610, Singapore. ${ }^{7}$ Singapore Gastric Cancer Consortium, Singapore 119074, Singapore. ${ }^{8}$ Functional Genomics Platform, Monash University, Clayton, VIC 3800, Australia. ${ }^{9}$ Monash Bioinformatics Platform, Monash University, Clayton, VIC 3800, Australia.

Published online: 25 March 2021

\section{Reference}

1. Davies R, Liu L, Taotao S, et al. CRISPRi enables isoform-specific loss-of-function screens and identification of gastric cancer-specific isoform dependencies. Genome Biol. 2021;22:47 https://doi.org/10.1186/s13059-021-02266-6. 